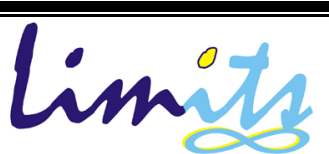

Limits: Journal of Mathematics and Its Applications

E-ISSN: 2579-8936

P-ISSN: 1829-605X

Vol. 18, No. 1, Mei 2021, 23-36

DOI: http://dx.doi.org/10.12962/limits.v18i1.8207

\title{
Model Matematika COVID-19 dengan Sumber Daya Pengobatan yang Terbatas
}

\author{
Utti Marina Rifanti ${ }^{1 *}$, Atika Ratna Dewi ${ }^{2}$, Nurlaili ${ }^{1}$ \\ ${ }^{1,2}$ Institut Teknologi Telkom Purwokerto (ITTP) Jalan D.I. Panjaitan No. 128 Purwokerto, Jawa Tengah \\ ${ }^{1}$ Fakultas Teknik Telekomunikasi dan Elektro ITTP \\ ${ }^{2}$ Fakultas Informatika ITTP \\ e-mail: marina@ittelkom-pwt.ac.id
}

Diajukan: 16 Desember 2020, Diperbaiki: 4 Februari 2021, Diterima: 31 Maret 2021

\begin{abstract}
Abstrak
Coronavirus 2019 (COVID-19) merupakan penyakit menular yang disebabkan oleh Severe Acute Respiratory Syndrome Coronavirus 2. Hingga Desember 2020, terdapat 617 ribu kasus terkonfirmasi positif COVID-19 dengan total 18 ribu kematian karena COVID-19 di Indonesia. Pada penelitian ini, kami menggunakan model kompartemen Susceptible-Exposed-Infected-Recovered (SEIR) untuk analisis dampak sumber daya pengobatan yang terbatas dan memprediksi dinamika penyebaran COVID-19 di Indonesia. Metode yang digunakan adalah penurunan angka rasio reproduksi dasar dan titik ekuilibrium menggunakan analisis sistem dinamik dalam bentuk persamaan diferensial non linier yang diperoleh dari model awal. Kemudian, kami menganalisis angka rasio reproduksi dasar dan titik ekuilibrium, serta memprediksi kondisi pandemi COVID-19 menggunakan kasus nyata di Indonesia sejak 2 Maret hingga 30 Nopember 2020. Dari hasil penelitian ini, diperoleh bahwa jika perubahan kasus terinfeksi $I(t)$ terhadap waktu $t$ kurang dari 2640 kasus, maka angka rasio reproduksi dasar menjadi kurang dari nol dan nilai $I(t)$ semakin mendekati nol saat mulai memasuki bulan Maret 2021. Hal tersebut berarti, jika ratarata kasus positif terkonfirmasi harian masih di bawah kapasitas maksimal sumber daya pengobatan, yaitu 2640 kasus, maka dari hasil analisis model diprediksikan bahwa penyakit akan mulai menghilang pada bulan Maret 2021. Sebaliknya, jika kasus positif terkonfirmasi harian di atas 2640 kasus, maka diperkirakan penyakit akan mulai menghilang pada Juni 2021.
\end{abstract}

Kata Kunci: COVID-19, model kompartemen SEIR, pengobatan

\begin{abstract}
Coronavirus disease 2019 (COVID-19) is an infectious disease caused by Severe Acute Respiratory Syndrome Coronavirus 2. There have been 617 thousand confirmed cases of COVID-19, including 18 thousand deaths in Indonesia, till December 2020. This article proposes the SusceptibleExposed-Infected-Recovered (SEIR) compartmental model for impact analysis of limited resources for treatment and predicts the long-term dynamic of COVID-19 in Indonesia. The method of deriving the basic reproduction ratio and the equilibrium points using dynamic systems analysis of the non-linear differential equations of the model is used in this study. Finally, we analyze our mathematical model results and predict the disease by considering the real Indonesian cases from March 2 to November 30, 2020. From the results of this study, it was found that if the change in infected cases $I(t)$ against time $t$ was less than 2640 cases, then the basic reproduction ratio was less than zero and the value of I ( $t)$ was getting closer to zero at the beginning of March 2021. This means that if the case average daily confirmed positive is still below the maximum capacity of treatment resources, namely 2640 cases, it is predicted that the disease will begin to disappear in March 2021. Conversely, if the daily positive cases are above 2640 cases, the disease will begin to disappear in June 2021.
\end{abstract}

Keywords: COVID-19, SEIR compartmental model, treatment 


\section{Pendahuluan}

Coronavirus 2019 (COVID-19) yang berasal dari Wuhan, China, merupakan penyakit yang disebabkan oleh Severe Acute Respiratory Syndrome Coronavirus 2 (SARS-CoV-2) [1]. Seorang individu dapat terkena virus ini dari individu lainnya yang telah positif terinfeksi COVID-19 terlebih dahulu. Penyebaran virus ini dapat terjadi melalui tetesan air liur yang berasal dari batuk atau bersin dari seseorang yang sedang terinfeksi COVID-19. Seseorang yang menyentuh tetesan air liur milik individu lainnya yang terinfeksi tersebut dapat menjadi terinfeksi COVID-19 apabila ia menghirup tetesan tersebut ataupun menyentuh bagian mata, hidung atau mulutnya tanpa mencuci tangannya terlebih dahulu [2]. Masa inkubasi COVID-19, yaitu waktu antara terpapar virus atau terinfeksi hingga timbulnya gejala, rata-rata 5 hingga 6 hari. Periode ini juga dikenal sebagai periode presymptomatic. Periode tersebut dapat menjadi petunjuk adanya gejala awal klinis yang terjadi dalam kurun waktu karantina selama 14 hari [3].

Berdasarkan data WHO pada Desember 2020, di Indonesia terdapat 617 ribu kasus terkonfirmasi positif COVID-19 dengan total 18 ribu kematian karena COVID-19 [4]. Kasus COVID-19 pertama di Indonesia terjadi pada 2 Maret 2020 [5]. Dalam hal ini pengobatan memainkan peran penting untuk mengontrol atau mengurangi penyebaran COVID-19, khususnya di Indonesia. Menurut data Kemkes RI, hingga saat ini terdapat 100 rumah sakit rujukan yang dapat melakukan perawatan terhadap pasien COVID-19 [6]. Sayangnya, jika pasien terkonfirmasi positif COVID-19 terus bertambah maka ruang perawatan pun akan semakin terbatas. Dalam model epidemi klasik, tingkat pengobatan diasumsikan sebanding dengan jumlah individu yang terinfeksi. Namun hal ini mustahil, karena dalam perspektif nyata sumber daya untuk pengobatan relatif terbatas jika dibandingkan dengan total populasi dalam suatu wilayah tertentu. Seperti yang terjadi pada awal bulan Nopember 2020, beberapa rumah sakit di Indonesia mengalami kekurangan ruang isolasi dan tenaga medis karena jumlah pasien COVID-19 yang mengalami peningkatan dalam beberapa waktu terakhir [7][8]. Setiap negara harus memiliki kapasitas yang sesuai untuk pengobatan. Jika terlalu besar, negara akan mengeluarkan biaya yang tidak perlu. Jika terlalu kecil, negara memiliki resiko terjadinya wabah penyakit. Jenis fungsi pengobatan dengan sumber daya pengobatan yang terbatas (limited treatment resource) lebih realistis karena di setiap negara ataupun wilayah jumlah tempat pengobatan, tenaga medis, maupun obat-obatan juga sangat terbatas. Oleh karena itu, pada penelitian ini diterapkan laju kesembuhan individu terinfeksi dengan pengobatan yang konstan untuk mensimulasikan sumber daya pengobatan yang terbatas.

Beberapa penelitian telah dilakukan untuk memodelkan penyebaran COVID-19. Model matematika digunakan pada beberapa penelitian di beberapa negara, seperti Cina [9][10][11], 
India [12][13], Italia [14], Meksiko [15], dan Indonesia [16][17]. Terdapat beberapa penelitian yang menggunakan kelompok individu laten sesuai dengan konsep masa inkubasi pada COVID19, yaitu model SEIR [18][19]. Model epidemi SEIR merupakan perluasan dari model SIR dengan menambahkan kelas laten (susceptible-exposed-infected-recovered). Berdasarkan pemaparan masalah tersebut, maka dalam penelitian ini penulis akan membahas masalah model penyebaran COVID-19 menggunakan model epidemi SEIR dengan sumber daya pengobatan yang terbatas.

\section{Metode Penelitian}

Model matematika yang akan digunakan untuk menggambarkan model penyebaran COVID-19 di Indonesia dalam penelitian ini adalah model epidemi SEIR. Populasi individu dibagi menjadi empat kelas, yaitu kelas Susceptible yang disimbolkan dengan $S$, kelas Exposed atau laten yang disimbolkan dengan $E$, kelas Infected yang disimbolkan dengan $I$, dan kelas Recovered yang disimbolkan dengan $R$. Individu rentan yang mengalami interaksi dengan individu yang telah positif terinfeksi COVID-19 akan menjadi individu laten. Setelah kurun waktu tertentu, individu laten tersebut mengalami peningkatan level infeksi COVID-19 sehingga individu tersebut masuk ke dalam kelompok individu yang positif terinfeksi dan dapat menularkan. Beberapa individu terinfeksi yang sudah mengalami pengobatan sesuai dengan prosedur akan sembuh dari COVID-19 dan masuk ke dalam kelompok individu sembuh. Selanjutnya diberikan asumsi-asumsi pada model SEIR dengan sumber daya pengobatan yang terbatas sebagai berikut.

a) Pertambahan individu dalam populasi disebabkan oleh dua faktor, yaitu kelahiran dan imigrasi. Pertambahan individu tersebut diasumsikan konstan.

b) Setiap individu yang masuk ke dalam populasi, baik karena faktor kelahiran maupun imigrasi, akan menjadi individu yang rentan terhadap COVID-19.

c) Setiap individu dapat mengalami kematian secara alami (bukan karena COVID-19) dengan tingkat kematian natural sebesar $\mu$.

d) Tingkat kematian karena COVID-19 sebesar $d$.

e) Individu pada kelas rentan yang melakukan kontak dengan individu yang positif terinfeksi COVID-19 dan menularkan akan masuk ke dalam kelas laten dengan tingkat keefektifan infeksi sebesar $\beta$.

f) Individu pada kelas laten akan berpindah ke dalam kelas terinfeksi karena adanya penambahan gejala COVID-19 dengan tingkat penambahan gejala sebesar $\epsilon$. 
g) Individu yang terinfeksi dapat sembuh karena dua faktor, yaitu karena adanya pengobatan (treatment) dengan tingkat kesembuhan karena pengobatan sebesar $c$ ataupun karena faktor kesembuhan alami karena daya tahan tubuh (imunitas) yang tinggi dengan tingkat kesembuhan $r$.

h) Adanya keterbatasan kapasitas sumber daya pengobatan. Kapasitas total individu terinfeksi $\left(I_{\max }\right)$ menunjukkan jumlah maksimal individu terinfeksi yang masih dapat ditampung oleh sumber daya pengobatan yang tersedia. Dengan kata lain $\left(I_{\max }\right)$ sebanding dengan kapasitas total sumber daya pengobatan. Apabila jumlah individu terinfeksi kurang dari atau sama dengan $\left(I_{\max }\right)$, maka individu yang dapat sembuh karena pengobatan sejumlah $c I$. Namun, apabila jumlah individu terinfeksi melebihi $I_{\max }$, maka individu yang dapat sembuh karena pengobatan menjadi konstan sejumlah $c I_{\max }$.

i) Individu yang sembuh mempunyai kekebalan (immune) terhadap COVID-19 atau tidak bisa menjadi rentan kembali.

Adapun parameter dari model ini didefinisikan sebagai berikut.

Tabel 1. Parameter Model SEIR

\begin{tabular}{|c|c|c|c|}
\hline Notasi & Definisi & Kondisi & Satuan \\
\hline$A$ & Jumlah kelahiran dan imigrasi & $A \geq 1$ & Orang per hari \\
\hline$\beta$ & Tingkat keefektifan infeksi COVID-19 & $0<\beta<1$ & Per hari \\
\hline$\mu$ & Tingkat kematian alami & $0<\mu<1$ & Per hari \\
\hline$\epsilon$ & Tingkat penambahan gejala COVID-19 & $0<\epsilon<1$ & Per hari \\
\hline$c$ & $\begin{array}{l}\text { Tingkat kesembuhan dari COVID-19 } \\
\text { karena faktor pengobatan }\end{array}$ & $0<c<1$ & Per hari \\
\hline$r$ & $\begin{array}{l}\text { Tingkat kesembuhan dari COVID-19 } \\
\text { secara alami }\end{array}$ & $0<r<1$ & Per hari \\
\hline$d$ & Tingkat kematian karena dari COVID-19 & $0<d<1$ & Per hari \\
\hline
\end{tabular}

Berikut ini adalah diagram kompartemen yang menggambarkan model penyebaran penyakit COVID-19 menggunakan model epidemi SEIR dengan sumber daya pengobatan yang terbatas sesuai dengan asumsi model.

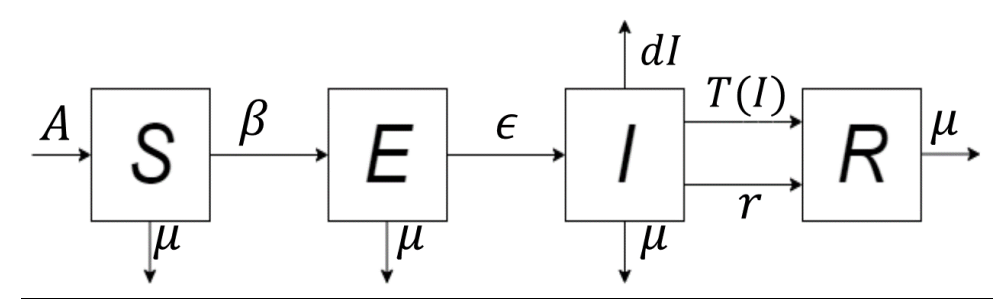

Gambar 1. Diagram Kompartemen Model 
Berdasarkan uraian penjelasan tersebut diperoleh sistem persamaan diferensial untuk model SEIR dengan sumber daya pengobatan yang terbatas adalah sebagai berikut

$$
\begin{aligned}
& \frac{d S}{d t}=A-\beta S I-\mu S \\
& \frac{d E}{d t}=\beta S I-(\mu+\epsilon) E \\
& \frac{d I}{d t}=\epsilon E-(\mu+r+d) I-T(I) \\
& \frac{d I}{d t}=r I-\mu R+T(I)
\end{aligned}
$$

Adapun fungsi pengobatan $T(I)$ didefinisikan sebagai berikut.

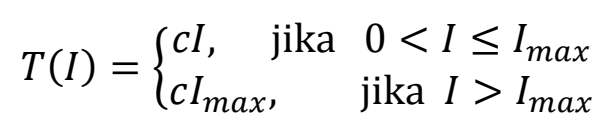

dengan $c I_{\text {max }}=k$. Pada proses perhitungan titik ekuilibrium selanjutnya, karena $R$ tidak berpengaruh pada persamaan pertama hingga ketiga pada Sistem (1) dan variabel $R$ dapat diperoleh dari variabel $I$, maka untuk sementara variabel $R$ dapat diabaikan. Langkah selanjutnya adalah menentukan titik ekuilibrium bebas penyakit dan analisis kestabilannya menggunakan beberapa teorema berikut.

Teorema 1 [20] Diberikan matriks Jacobian $J f(X)$ dari sistem persamaan Diferensial Nonlinear.

1. Jika semua bagian real nilai eigen dari matriks $J f(X)$ bernilai negatif, maka titik ekuilibrium X stabil asimtotik lokal.

2. Jika terdapat paling sedikit satu nilai eigen dari matriks $J f(X)$ yang bagian realnya bernilai positif, maka titik ekuilibrium X tidak stabil

Teorema 2 [21] Misal M matriks berukuran $3 \times 3$ dengan entri-entri bilangan real. Jika $\operatorname{Tr}(M)$, $\operatorname{det}(M)$, dan $\operatorname{det}\left(M^{[2]}\right)$ semuanya bernilai kurang dari nol, maka semua nilai eigen dari matriks $M$ mempunyai bagian real yang negatif.

\section{Hasil dan Pembahasan}

Pada bagian ini akan dibahas terlebih dahulu mengenai eksistensi titik ekuilibrium bebas penyakit dari Sistem (1). Titik ekuilibrium bebas penyakit Sistem (1) diperoleh dengan menentukan $\frac{d S}{d t}=0, \frac{d E}{d t}=0$, dan $\frac{d I}{d t}=0$ dengan nilai $I=0$, yaitu

$$
X_{0}=\left(S_{0}, E_{0}, I_{0}\right)=\left(\frac{A}{\mu}, 0,0\right)
$$


Berdasarkan Sistem (1) dan Persamaan (3) diperoleh angka rasio reproduksi dasar sebagai berikut.

$$
R_{0}=\frac{\epsilon \beta A}{\mu(\mu+\epsilon)(\mu+r+d+c)}
$$

Selanjutnya untuk menentukan titik ekuilibrium endemik, kondisi endemik akan dibagi menjadi dua kasus sesuai dengan definisi fungsi pengobatan, yaitu $0<I \leq I_{\max }$ dan $I>I_{\max }$.

3.1. Kasus Endemik 1

Kasus endemik yang pertama yaitu ketika nilai jumlah individu terinfeksi dan menularkan masih kurang dari atau sama dengan kapasitas total individu terinfeksi, atau dapat dituliskan $0<I \leq I_{\max }$, maka Sistem (1) menjadi

$$
\begin{aligned}
& A-\beta S I-\mu S=0 \\
& \beta S I-(\mu+\epsilon) E=0 \\
& \epsilon E-(\mu+r+d+c) I=0
\end{aligned}
$$

Dari Sistem (5) dengan kondisi $0<I \leq I_{\max }$ diperoleh titik ekuilibrium endemik yang pertama adalah $X_{1}=\left(S_{1}, E_{1}, I_{1}\right)$ dengan

$S_{1}=\frac{A}{\mu R_{0}}$

$E_{1}=\frac{\mu(\mu+r+d+c)}{\epsilon \beta}\left(R_{0}-1\right)$, dan

$I_{1}=\frac{\mu}{\beta}\left(R_{0}-1\right)$

Titik ekuilibrium $X_{1}=\left(S_{1}, E_{1}, I_{1}\right)$ ada dan bernilai positif jika $1<R_{0}<p_{0}$, dengan

$p_{0}=1+\frac{\beta}{\mu} I_{\max }$

3.2. Kasus Endemik 2

Selanjutnya, Sistem (1) akan diuraikan sesuai dengan kasus kedua pada definisi fungsi pengobatan yaitu apabila $I>I_{\max }$ sehingga menjadi Sistem (6) sebagai berikut.

$$
\begin{aligned}
& A-\beta S I-\mu S=0 \\
& \beta S I-(\mu+\epsilon) E=0 \\
& \epsilon E-(\mu+r+d) I-k=0
\end{aligned}
$$

Dari Sistem (6) dengan kondisi $I>I_{\max }$ diperoleh titik ekuilibrium endemik yang pertama adalah $X_{2}=\left(S_{2}, E_{2}, I_{2}\right)$ dengan

$$
\begin{aligned}
& S_{2}=\frac{A}{\beta I_{2}+\mu}, \\
& E_{2}=\frac{(\mu+r+d) I_{2}+k}{\epsilon}, \text { dan } \\
& I_{2}=\frac{-b_{1} \pm \sqrt{\Delta_{1}}}{2 \beta(\mu+\epsilon)(\mu+r+d)} .
\end{aligned}
$$


dimana

$b_{1}=(\mu+\epsilon)(\beta k+\mu(\mu+r+d)-\mu(\mu+r+d+c) R 0)$, dan

$\Delta_{1}=(\mu+\epsilon)^{2}\left[(\beta k+\mu(\mu+r+d)-\mu(\mu+r+d+c) R 0)^{2}-4 \beta k \mu(\mu+r+d)\right]$.

Titik ekuilibrium $X_{2}=\left(S_{2}, E_{2}, I_{2}\right)$ ada dan bernilai positif jika $R_{0}>p_{2}$ dan $R_{0}>p_{3}$, dengan

$p_{2}=1+\frac{\beta k-\mu c}{\mu(\mu+r+d+c)}+\frac{2 \sqrt{\mu \beta k(\mu+r+d)}}{\mu(\mu+r+d+c)}$, dan

$p_{3}=1+\frac{\beta k-\mu c+2 \beta(\mu+r+d) I_{\max }}{\mu(\mu+r+d+c)}$.

\subsection{Analisis Kestabilan Titik Ekuilibrium Bebas Penyakit}

Pada bagian ini, akan dibahas mengenai kestabilan lokal titik ekuilibrium bebas penyakit Sistem (1). Persamaan karakteristik dari Sistem (1) yang terlinearisasi di sekitar titik ekuilibrium bebas penyakit $X_{0}$ dinyatakan dalam Persamaan (7) sebagai berikut.

$$
\begin{aligned}
& \left|\begin{array}{ccc}
-(\mu+\lambda) & 0 & -\frac{\beta A}{\mu} \\
0 & -(\mu+\epsilon+\lambda) & \frac{\beta A}{\mu} \\
0 & \epsilon & -(\mu+r+d+c+\lambda)
\end{array}\right|=0 \\
& \Leftrightarrow(\mu+\lambda)\left(-(\mu+\epsilon+\lambda)(\mu+r+d+c+\lambda)+\frac{\epsilon \beta A}{\mu}\right)=0
\end{aligned}
$$

Dari Persamaan (7) diperoleh $\lambda_{1}=-\mu, \lambda_{2,3}=-\frac{1}{2 \mu}(m \pm \sqrt{n})$ dengan

$m=\mu(2 \mu+\epsilon+r+d+c)$ dan

$n=\mu^{2}\left(\epsilon^{2}+r^{2}+d^{2}+c^{2}-2(\epsilon r+\epsilon d+\epsilon c-r d-r c-d c)\right)+4 \mu \epsilon \beta A$.

Oleh karena di titik ekuilibrium bebas penyakit $X_{0}$ nilai $R_{0}<1$, maka $m>\sqrt{n}$. Sehingga nilai eigen $\lambda_{i}<0$ untuk setiap $i=1,2,3$. Sehingga dapat disimpulkan bahwa jika $R_{0}<1$, maka titik ekuilibrium bebas penyakit Sistem (1) stabil asimtotik lokal.

Hal ini berarti apabila angka rasio reproduksi dasar bernilai lebih kecil dari 1, dengan jumlah individu mula-mula di dalam populasi untuk masing-masing sub populasi individu cukup dekat dengan jumlah individu pada titik ekuilibrium bebas penyakit $X_{0}$, maka dalam jangka waktu yang cukup lama penyakit akan menghilang dari populasi. Dengan kata lain, jika angka rasio reproduksi dasar bernilai kurang dari 1, maka jumlah individu yang terinfeksi penyakit akan mendekati jumlah individu pada titik ekuilibrium Hal ini menunjukkan bahwa saat angka reproduksi dasar kurang dari atau sama dengan 1, maka jumlah individu terinfeksi dan menularkan dalam populasi akan berkurang menuju 0 , sehingga lama kelamaan penyakit akan menghilang dari populasi. 
3.4. Analisis Kestabilan Titik Ekuilibrium Endemik

Pada bagian ini, akan dibahas mengenai kestabilan lokal titik ekuilibrium endemik Sistem (1). Persamaan karakteristik dari Sistem (1) yang terlinearisasi di sekitar titik ekuilibrium endemik $X_{1}$ dinyatakan dalam Persamaan (8) sebagai berikut.

$$
\left|\begin{array}{ccc}
-\left(\mu R_{0}+\lambda\right) & 0 & -\frac{\beta A}{\mu R_{0}} \\
\mu\left(R_{0}-1\right) & -(\mu+\epsilon+\lambda) & \frac{\beta A}{\mu R_{0}} \\
0 & \epsilon & -(\mu+r+d+c+\lambda)
\end{array}\right|=0
$$

dengan

$a_{2}=\mu\left(1+R_{0}\right)+\epsilon+r+d+c>0$,

$b_{2}=\mu R_{0}(2 \mu+\epsilon+r+d+c)>0$, dan

$c_{2}=\mu(\mu+\epsilon)(\mu+r+d+c)\left(R_{0}-1\right)$.

Pada kasus titik ekuilibrium endemik berlaku nilai $R_{0}>1$, sehingga nilai $c_{2}>0$. Dengan demikian nilai $a_{2}>0, b_{2}>0, a_{2} b_{2}-c_{2}>0$, dan $c_{2}>0$ jika memenuhi nilai $R_{0}>1$. Dengan demikian, setiap nilai eigen dari Persamaan (...) bernilai kurang dari nol. Dengan kata lain, jika $R_{0}>1$ maka titik ekuilibrium endemik $X_{1}$ Sistem (1) stabil asimtotik lokal.

Artinya jika angka rasio reproduksi dasar bernilai lebih besar dari 1, dengan jumlah individu awal dalam populasi untuk masing-masing sub populasi individu cukup dekat dengan jumlah individu pada titik ekuilibrium endemik $X_{1}$, maka dalam jangka waktu yang cukup lama penyakit akan tetap ada dalam populasi. Dengan kata lain, jika angka rasio reproduksi dasar bernilai lebih besar dari 1, maka jumlah individu yang terinfeksi penyakit akan mendekati jumlah individu pada titik ekuilibrium $X_{1}$.

3.5. Analisis Kestabilan Titik Ekuilibrium Bebas Penyakit

Pada bagian ini, akan dibahas mengenai kestabilan lokal titik ekuilibrium endemik $X_{2}$ Sistem (1) menggunakan matriks second additive compound. Sebelumnya, ditentukan terlebih dahulu Matriks Jacobian di sekitar titik ekuilibrium endemik $X_{2}$ sebagai berikut.

$$
J f\left(X_{2}\right)=\left[\begin{array}{ccc}
-\left(\beta I_{2}+\mu\right) & 0 & -\beta S_{2} \\
\beta I_{2} & -(\mu+\epsilon) & \beta S_{2} \\
0 & \epsilon & -(\mu+r+d+c)
\end{array}\right]
$$

Matriks second additive compund dari hasil linearisasi Sistem (1) di sekitar titik ekuilibrium endemik $X_{2}$ dinyatakan dalam 


$$
J f\left(X_{2}\right)^{[2]}=\left[\begin{array}{ccc}
-\left(\beta I_{2}+2 \mu+\epsilon\right) & \beta S_{2} & \beta S_{2} \\
\epsilon & -\left(\beta I_{2}+2 \mu+\epsilon\right) & 0 \\
0 & \beta I_{2} & -(2 \mu+\epsilon+r+d)
\end{array}\right]
$$

Dari matriks $J f\left(X_{2}\right)$ dan $J f\left(X_{2}\right)^{[2]}$ diperoleh bahwa

$\operatorname{Tr}\left(J f\left(X_{2}\right)\right)=-\left(\beta I_{2}+3 \mu+\epsilon+r+d\right)$,

$\operatorname{det}\left(J f\left(X_{2}\right)\right)=-\left(\mu(\mu+\epsilon)+\epsilon \beta I_{2}-\mu \beta\left(I_{2}(\mu+r+d)-\epsilon S_{2}\right)\right)$, dan

$\operatorname{det}\left(J f\left(X_{2}\right)^{[2]}\right)=-(2 \mu+\epsilon)\left(\beta I_{2}+2 \mu+r+d\right)(2 \mu+\epsilon+r+d)-\beta^{2} I_{2}\left(I_{2}(2 \mu+\epsilon+\right.$

$\left.r+d)-\epsilon S_{2}\right)-\beta(2 \mu+\epsilon+r+d)\left(I_{2}(2 \mu+r+d)-\epsilon S_{2}\right)$

Selanjutnya diketahui bahwa

$$
\frac{S_{2}}{I_{2}}<\frac{\mu+r+d}{\epsilon} .
$$

Jika berlaku Pertidaksamaan (11), maka $\operatorname{det}\left(J f\left(X_{2}\right)\right)<0$ dan $\operatorname{det}\left(J f\left(X_{2}\right)^{[2]}\right)<0$. Selanjutnya, menurut Teorema (2) diperoleh bahwa semua bagian real dari nilai eigen matriks $J f\left(X_{2}\right)$ bernilai kurang dari nol. Dengan kata lain, jika berlaku Pertidaksamaan (11), maka titik ekuilibrium endemik $X_{2}$ dari Sistem (1) stabil asimtotik lokal.

Hal ini berarti, apabila perbandingan jumlah individu rentan dengan individu terinfeksi dan menularkan lebih kecil daripada $\frac{\mu+r+d}{\epsilon}$ dengan jumlah individu mula mula di dalam populasi untuk masing-masing sub populasi individu cukup dekat dengan jumlah individu pada titik ekuilibrium endemik $X_{2}$, maka dalam jangka waktu yang cukup lama penyakit akan tetap ada dalam populasi. Dengan kata lain, jika jumlah individu rentan lebih kecil daripada jumlah individu terinfeksi dan menularkan, maka jumlah individu yang terinfeksi penyakit akan mendekati jumlah individu pada titik ekuilibrium $X_{2}$.

\subsection{Simulasi Model}

Simulasi model dilakukan dengan menggunakan Software Matlab yang bertujuan untuk melengkapi hasil-hasil yang telah diperoleh secara analisis pada bagian sebelumnya. Pada bagian ini dilakukan simulasi untuk mengetahui perilaku dinamik penyelesaian Sistem (1). Simulasi model pada Sistem (1) menggunakan data COVID-19 di Indonesia yang diambil sejak 2 Maret hingga 30 Nopember 2020 [22]. Berikut adalah grafik yang menunjukan jumlah kasus terkonfirmasi harian COVID-19. 


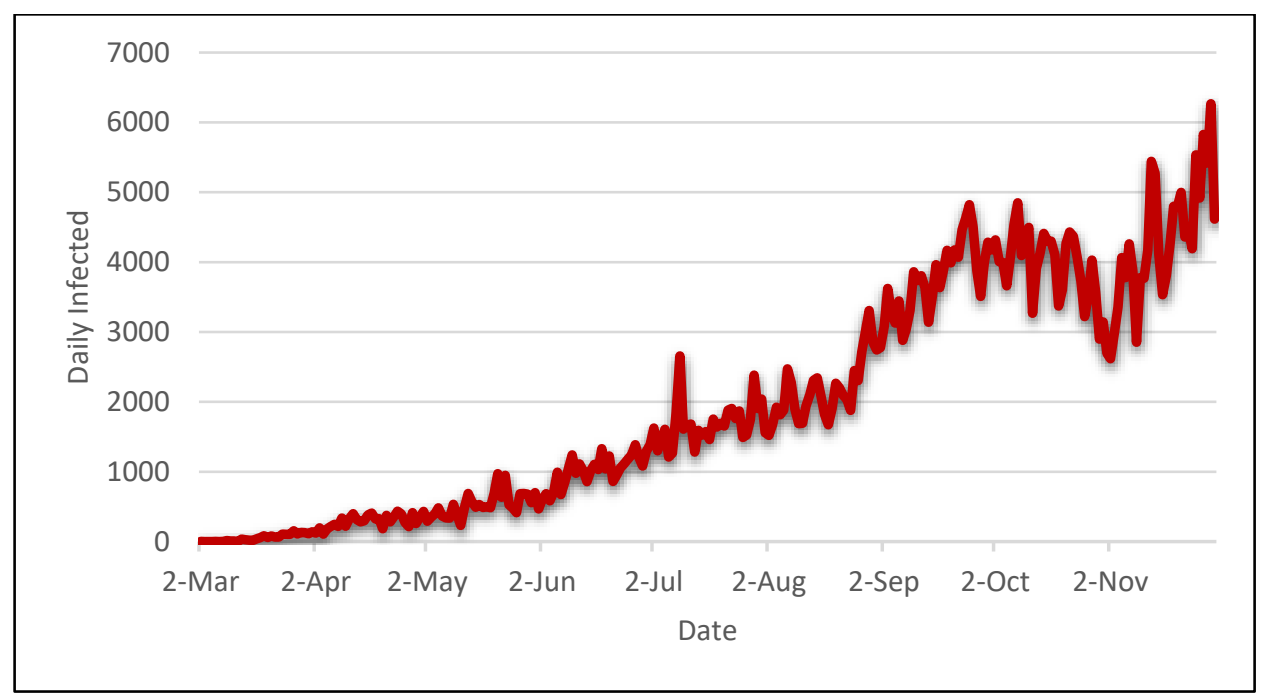

Gambar 2. Kasus Infeksi Harian COVID-19

Adapun nilai-nilai parameter yang digunakan adalah sebagai berikut.

Tabel 2. Nilai Parameter Simulasi Model SEIR

\begin{tabular}{|c|c|c|c|c|}
\hline Notasi & Definisi & Nilai & Satuan & Sumber \\
\hline$A$ & Jumlah kelahiran dan imigrasi & 1095 & Orang per hari & [23] \\
\hline$\mu$ & Tingkat kematian alami & $3.78 \times 10^{-5}$ & Per hari & [23] \\
\hline$\epsilon$ & Tingkat penambahan gejala COVID-19 & 0.2 & Per hari & [3] \\
\hline$c$ & $\begin{array}{l}\text { Tingkat kesembuhan dari COVID-19 } \\
\text { karena faktor pengobatan }\end{array}$ & $5 \times 10^{-3}$ & Per hari & [22] \\
\hline$r$ & $\begin{array}{l}\text { Tingkat kesembuhan dari COVID-19 } \\
\text { secara alami }\end{array}$ & $2 \times 10^{-3}$ & Per hari & diasumsikan \\
\hline$d$ & Tingkat kematian karena dari COVID-19 & $3.4 \times 10^{-2}$ & Per hari & [22] \\
\hline$I_{\max }$ & $\begin{array}{l}\text { Kapasitas maksimal individu terinfeksi } \\
\text { yang masih dapat ditampung oleh sumber } \\
\text { daya pengobatan yang tersedia }\end{array}$ & 2640 & Orang per hari & [24] \\
\hline
\end{tabular}

Adapun nilai parameter tingkat keefektifan infeksi COVID-19, $\beta=2.74 \times 10^{-7}$, diperoleh dengan mensubstitusikan nilai parameter lainnya ke dalam persamaan pertama dari Sistem (1). Sedangkan nilai $I_{\max }=2640$ berasal dari jumlah rumah sakit rujukan COVID-19, yaitu $132 \mathrm{RS}$, dengan asumsi bahwa setiap rumah sakit dapat menampung 20 pasien COVID-19 setiap harinya. Selanjutnya simulasi model dilakukan dengan menampilkan grafik kelas individu yang positif terinfeksi COVID-19 dan kelas individu yang telah sembuh dari COVID-19. 


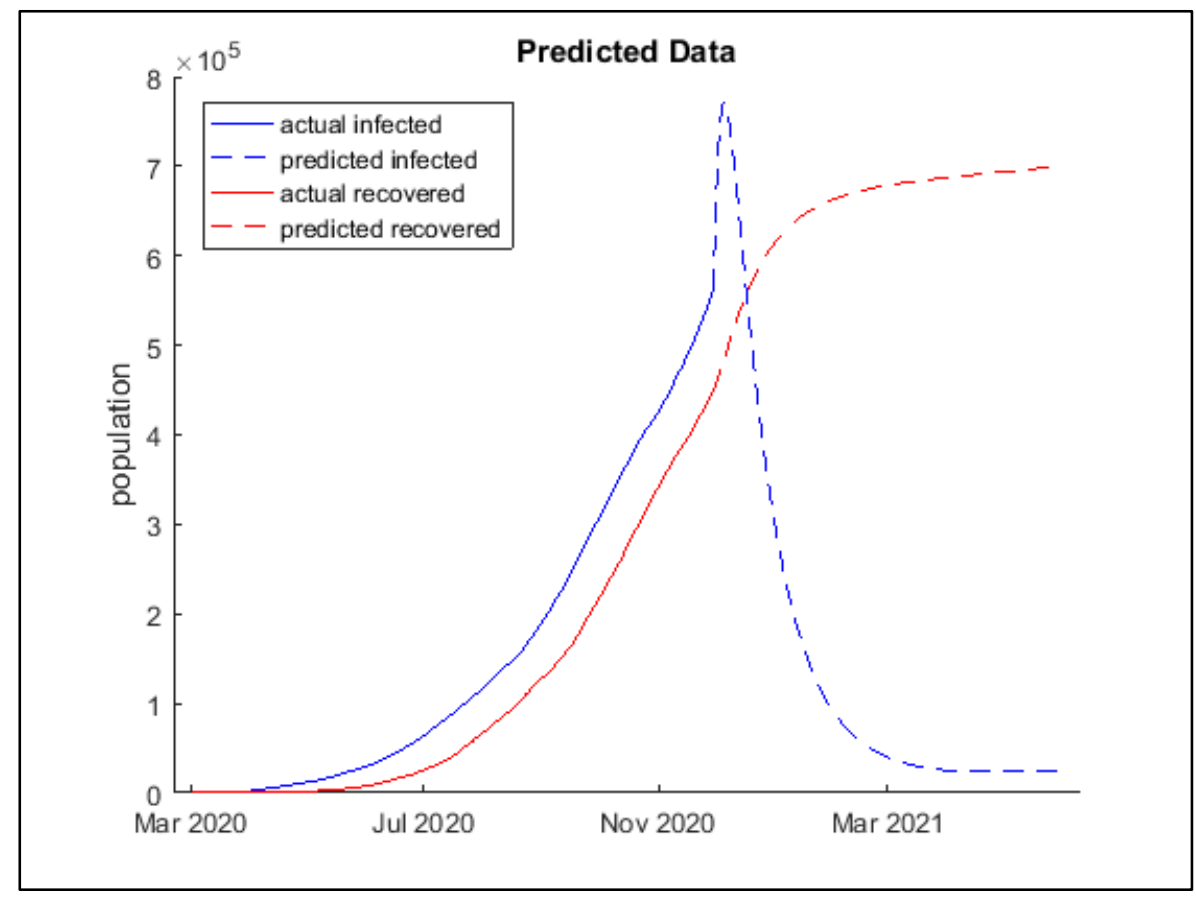

Gambar 3. Simulasi Model Kasus Endemik 1

Pada Gambar 3 terlihat bahwa pada kondisi endemik pertama, dimana $0<I \leq I_{\max }$, dapat diprediksikan bahwa penyebaran COVID-19 akan mulai menghilang setelah Maret 2021. Dengan kata lain, jika jumlah rata-rata kasus terkonfirmasi positif COVID-19 harian masih di bawah 2640 orang, maka diprediksikan bahwa penyebaran COVID-19 akan mulai menghilang setelah Maret 2021. Pada kasus ini, jumlah sumber daya pengobatan diasumsikan masih mencukupi dan masih mampu menampung seluruh pasien yang terkonfirmasi positif COVID-19.

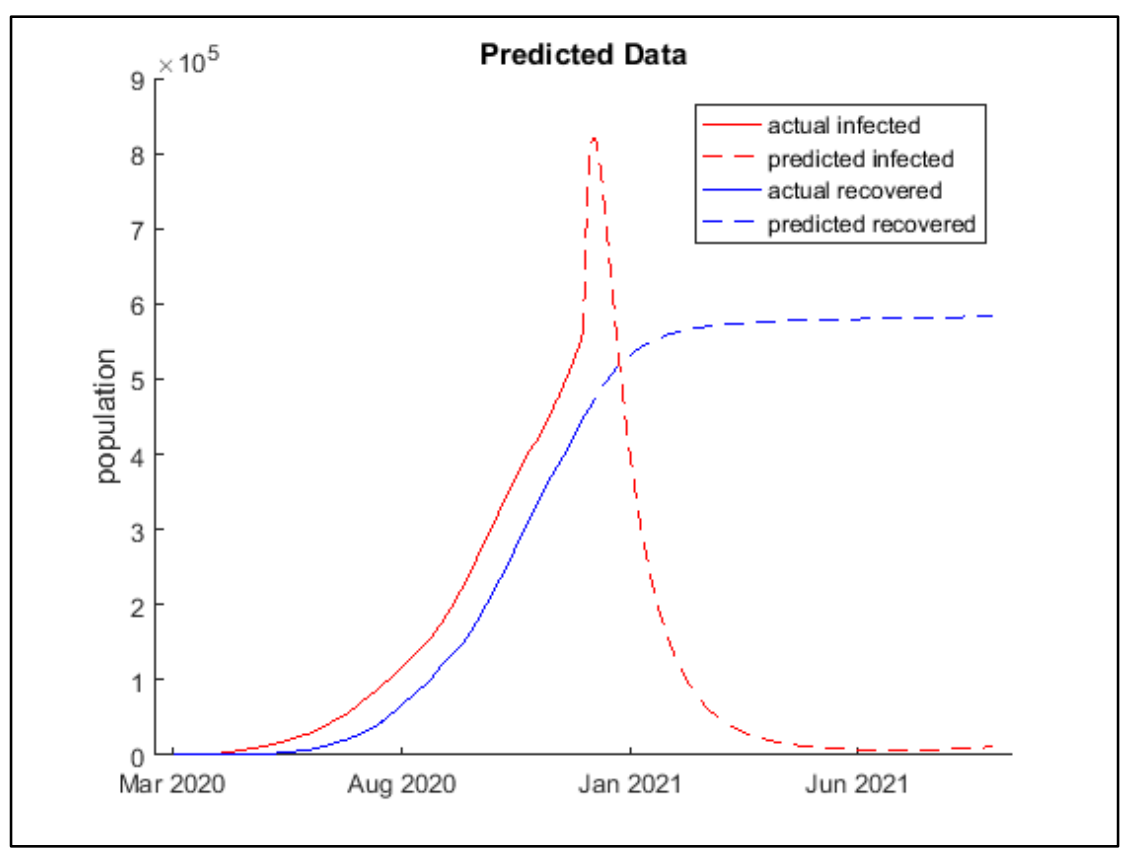

Gambar 4. Simulasi Model Kasus Endemik 2 
Sebaliknya, pada kasus endemik kedua, dimana $I>I_{\max }$, dapat diprediksikan bahwa penyebaran COVID-19 akan mulai menghilang setelah Juni 2021 seperti yang terlihat pada Gambar 4. Pada kasus ini diasumsikan bahwa rata-rata kapasitas maksimal pada rumah sakit rujukan COVID-19 di Indonesia adalah 2640 pasien. Jika dibandingkan dengan Gambar 3, pada kasus endemik kedua ini jumlah individu yang mengalami kesembuhan tidak lebih tinggi dibandingkan dengan kasus endemik yang pertama. Hal tersebut dikarenakan adanya keterbatasan sumber daya pengobatan yang terjadi, sehingga terdapat beberapa kasus terkonfirmasi positif COVID-19 yang tidak tertangani dan pada akhirnya tingkat kematian karena COVID-19 menjadi lebih tinggi jika dibandingkan dengan kasus endemik 1.

\section{Simpulan}

Dalam penelitian ini, diselidiki tentang perilaku penyebaran COVID-19 serta kaitannya dengan kapasitas sumber daya pengobatan yang ada di Indonesia. Model dirumuskan untuk memahami mekanisme penyebaran COVID-19 dengan mempertimbangkan faktor inkubasi dan kapasitas sumber daya pengobatan. Hingga Desember 2020, kasus terkonfirmasi COVID-19 di Indonesia masih terus terjadi dan cenderung meningkat dari hari ke hari. Berdasarkan hasil penelitian, sumber daya pengobatan memainkan peran yang sangat penting dalam menekan laju penyebaran COVID-19. Dari hasil penelitian ini diperkirakan penyakit akan mulai menghilang pada bulan Maret 2021 jika rata-rata kasus positif harian masih di bawah kapasitas maksimal sumber daya pengobatan, yaitu 2640 kasus. Sebaliknya, jika kasus positif harian di atas 2640 kasus, maka diperkirakan penyakit baru akan mulai menghilang pada Juni 2021.

\section{Ucapan Terima Kasih}

Artikel ini merupakan salah satu hasil penelitian internal kami di Institut Teknologi Telkom Purwokerto (ITTP). Kami mengucapkan terima kasih kepada Lembaga Penelitian dan Pengabdian kepada Masyarakat (LPPM) ITTP atas dukungan spiritual dan materilnya sehingga penelitian ini dapat berjalan dengan lancar. Terima kasih juga kepada semua rekan yang telah membantu penelitian ini, termasuk departemen dan kelompok ahli penelitian masing-masing. Semoga di kemudian hari kita dapat berkolaborasi dalam penelitian lain yang lebih baik lagi.

\section{Daftar Pustaka}

[1] T. Hu, Y. Liu, M. Zhao, Q. Zhuang, L. Xu, and Q. He, “A comparison of COVID-19, SARS and MERS," PeerJ, vol. 8, no. e9725, pp. 1-30, 2020. 
[2] World Health Organization, "QA for public," 2020. [Online]. Available: https://www.who.int/indonesia/news/novel-coronavirus/qa-for-public. [Accessed: 15-Sep2020].

[3] World Health Organization, "Coronavirus disease 2019 (COVID-19) Situation Report 73," Geneva, 2020.

[4] World Health Organization, "WHO Coronavirus Disease (COVID-19) Dashboard," 2020. [Online]. Available: https://covid19.who.int/table. [Accessed: 15-Sep-2020].

[5] R. Nuraini, “Kasus Covid-19 Pertama, Masyarakat Jangan Panik,” Portal Informasi Indonesia, 2020. [Online]. Available: https://indonesia.go.id/narasi/indonesia-dalamangka/ekonomi/kasus-covid-19-pertama-masyarakat-jangan-panik. [Accessed: 11-Sep2020].

[6] K. K. RI, “Daftar Rumah Sakit Rujukan COVID-19 Di Indonesia,” 2020. [Online]. Available: https://infeksiemerging.kemkes.go.id/.

[7] A. Bebey, "Ruang Isolasi Covid-19 Penuh, RSUD Oper Pasien Baru ke Rumah Sakit Lain," Merdeka.com, 2020. [Online]. Available:

https://www.merdeka.com/peristiwa/ruang-isolasi-covid-19-penuh-rsud-oper-pasien-baruke-rumah-sakit-lain.html.

[8] M. Gusti, "Kasus Corona Bertambah, Ruang Isolasi RS Rujukan Penuh," Kompas TV, 2020. [Online]. Available: https://www.kompas.tv/article/130793/kasus-coronabertambah-ruang-isolasi-rs-rujukan-penuh.

[9] Q. Lin et al., "A conceptual model for the coronavirus disease 2019 ( COVID-19) outbreak in Wuhan, China with individual reaction and governmental action," Int. J. Infect. Dis., vol. 93, no. 2020, pp. 211-216, 2020.

[10] S. Yang et al., "Early estimation of the case fatality rate of COVID-19 in mainland China : a data-driven analysis," Ann. Transl. Med., vol. 8, no. 4, pp. 6-11, 2020.

[11] N. Chen et al., "Epidemiological and clinical characteristics of 99 cases of 2019 novel coronavirus pneumonia in Wuhan, China : a descriptive study," Lancet, vol. 6736, no. 20, pp. 30211-30217, 2020.

[12] B. Kumar and B. K. Sapra, "A data driven epidemic model to analyse the lockdown effect and predict the course of COVID-19 progress in India," Chaos, Solitons and Fractals, vol. 139, no. 2020, pp. 1-9, 2020.

[13] A. Mahajan, N. A. Sivadas, and R. Solanki, “An epidemic model SIPHERD and its application for prediction of the spread of COVID-19 infection in India," Chaos, Solitons Fractals, vol. 140, no. 2020, pp. 1-6, 2020. 
[14] Y. Ding and L. Gao, "An evaluation of COVID-19 in Italy: A data-driven modeling analysis," Infect. Dis. Model., vol. 5, no. 2020, pp. 495-501, 2020.

[15] U. A. De León, Á. G. C. Pérez, and E. Avila-vales, “An SEIARD epidemic model for COVID-19 in Mexico : Mathematical analysis and state-level forecast," Chaos, Solitons Fractals, vol. 140, no. 2020, pp. 1-23, 2020.

[16] S. Setiati and M. K. Azwar, "COVID-19 and Indonesia," Acta Medica Indones. - Indones. J. Intern. Med., vol. 52, no. 1, pp. 84-89, 2020.

[17] D. Aldila et al., "A mathematical study on the spread of COVID-19 considering social distancing and rapid assessment: The case of Jakarta , Indonesia," Chaos, Solitons and Fractals, vol. 139, no. 2020, pp. 1-14, 2020.

[18] E. Soewono, "On the analysis of Covid-19 transmission in Wuhan, Diamond Princess and Jakarta-cluster," Commun. Biomath. Sci., vol. 3, no. 1, pp. 9-18, 2020.

[19] Z. A. Putra and S. A. Z. Abidin, "Application of SEIR Model in COVID-19 and The Effect of Lockdown on Reducing The Number of Active Cases," Indones. J. Sci. Technol., vol. 5, no. 2, pp. 185-192, 2020.

[20] W. E. Boyce and R. C. DiPrima, Elementary Differential Equations with Boundary Value Problems, 10th Editi. New Jersey: Prentice-Hall, 2012.

[21] S. A. Al-Sheikh, "Modeling and Analysis of an SEIR Epidemic Model with a Limited Resource for Treatment," Glob. J. Sci. Front. Res. Math. Decis. Sci., vol. 12, no. 14, pp. 57-66, 2012.

[22] S. COVID-19, "Peta Sebaran COVID-19," https://covid19.go.id/, 2020. [Online]. Available: https://covid19.go.id/peta-sebaran-covid19.

[23] Bappenas and BPS, "Proyeksi Penduduk Indonesia (Indonesia Population Projection)," Jakarta, 2013.

[24] K. K. RI, “Daftar Rumah Sakit Rujukan COVID-19 Di Indonesia,” kemkes.go.id, 2020. [Online]. Available:

https://infeksiemerging.kemkes.go.id/download/Daftar_RS_rujukan_COVID-19.pdf. 